\title{
Two species of Tortanus (Eutortanus) (Copepoda: Calanoida: Tortanidae) new to Korea
}

\author{
Byung-Jin Lim and Gi-Sik Min* \\ Department of Biological Sciences, Inha University, Incheon 402-751, Korea \\ *Correspondent: mingisik@inha.ac.kr
}

Two species of Tortanus (Eutortanus) are newly recorded from shallow Korean waters: T. (E.) vermiculus Shen, 1955 and T. (E.) komachi Itoh, Ohtsuka and Sato, 2001. As a result of this study, five species are reported in the subgenus of the family Tortanidae in Korea. The sequence of cytochrome $c$ oxidase subunit 1 (CO1) is also provided as a molecular characteristic.

Keywords: cytochrome $c$ oxidase subunit 1, Eutortanus, Korean waters, Tortanidae

(C) 2014 National Institute of Biological Resources

DOI: 10.12651/JSR.2014.3.1.027

\section{INTRODUCTION}

The planktonic calanoid copepod genus Tortanus consists of five subgenera: Tortanus Giesbrecht, 1892, Eutortanus Smirnov, 1935, Acutanus Ohtsuka, 1992, Atortus Ohtsuka, 1992 and Boreotortanus Ohtsuka and Reid, 1998.

Among them, the subgenus Eutortanus Smirnov, 1935 is distributed exclusively in subtropical/temperate brackish waters in East Asia (Ohtsuka et al., 1992; 1995) and comprises seven species: $T$. (E.) derjugini Smirnov, 1935, T. (E.) dextrilobatus Chen and Zhang, 1965, T. (E.) komachi Itoh, Ohtsuka and Sato, 2001, T. (E.) sheni Hulsemann, 1988, T. (E.) spinicaudatus Shen and Bai, 1956, T. (E.) terminalis Ohtsuka and Reid, 1998 and T. (E.) vermiculus Shen, 1955. Although these species are likely to occur in Korean waters due to geographical proximity, only three species, $T$. (E.) derjugini, $T$. (E.) dextrilobatus and $T$. (E.) spinicaudatus have so far been reported (Kim, 1985; Ohtsuka et al., 1992; 1995; Soh, 2010).

In this study, we collected two tortanid copepods, $T$. (E.) vermiculus and T. (E.) komachi, which are reported for the first time to the Korean copepod fauna. In addition, sequences of the mitochondrial cytochrome $c$ oxidase subunit $1(\mathrm{CO} 1)$ were also obtained for their molecular characteristics.

\section{Materials ANd Methods}

\section{Morphological taxonomy}

$T$. (E.) vermiculus and T. (E.) komachi were collected from Ganghwado Island (Incheon) and three localities on the east coast of Korea, respectively. The specimens were preserved in $95 \%$ ethanol immediately after collection. The appendages of the specimens were dissected in glycerol on a slide glass under a stereomicroscope (Olympus SZX-7; Olympus, Tokyo, Japan) and observed using a light microscope (Leica DM 2500; Leica Microsystems, Wetzlar, Germany). All drawings and measurements were made with the aid of a drawing tube.

The Roman and Arabic numerals in the armature formula represent spines and setae, respectively. All voucher specimens are deposited in the National Institute of Biological Resources (NIBR), Incheon, Korea.

\section{Molecular taxonomy}

Single antennule was removed from each specimen for genomic DNA extraction. The other body parts were used for the morphological observation. The genomic DNA was extracted using a RED Extract-N-Amp Tissue PCR kit (Sigma-Aldrich, St. Louis, MO, USA) according to the manufacturer's instructions. Mitochondrial CO1 was amplified by polymerase chain reaction (PCR) using universal primers of LCO1490 and HCO2198 (Folmer et al., 1994). PCR amplification was carried out under the following conditions: $3 \mathrm{~min}$ at $94^{\circ} \mathrm{C}, 35$ cycles of $95^{\circ} \mathrm{C}$ for $15 \mathrm{sec}, 48^{\circ} \mathrm{C}$ for $30 \mathrm{sec}$, and $72^{\circ} \mathrm{C}$ for $90 \mathrm{sec}$, with a final $72^{\circ} \mathrm{C}$ extension reaction for $7 \mathrm{~min}$. The PCR products were gel-purified using a QIAquick ${ }^{\circledR}$ Gel Extraction Kit (Qiagen, Valencia, CA, USA) and sequenced with an ABI PRISM ${ }^{\circledR} 3700$ DNA Analyzer using a BigDye Terminator Cycle Sequencing Ready Reaction Kit (Applied Biosystems, Foster City, CA, USA). 


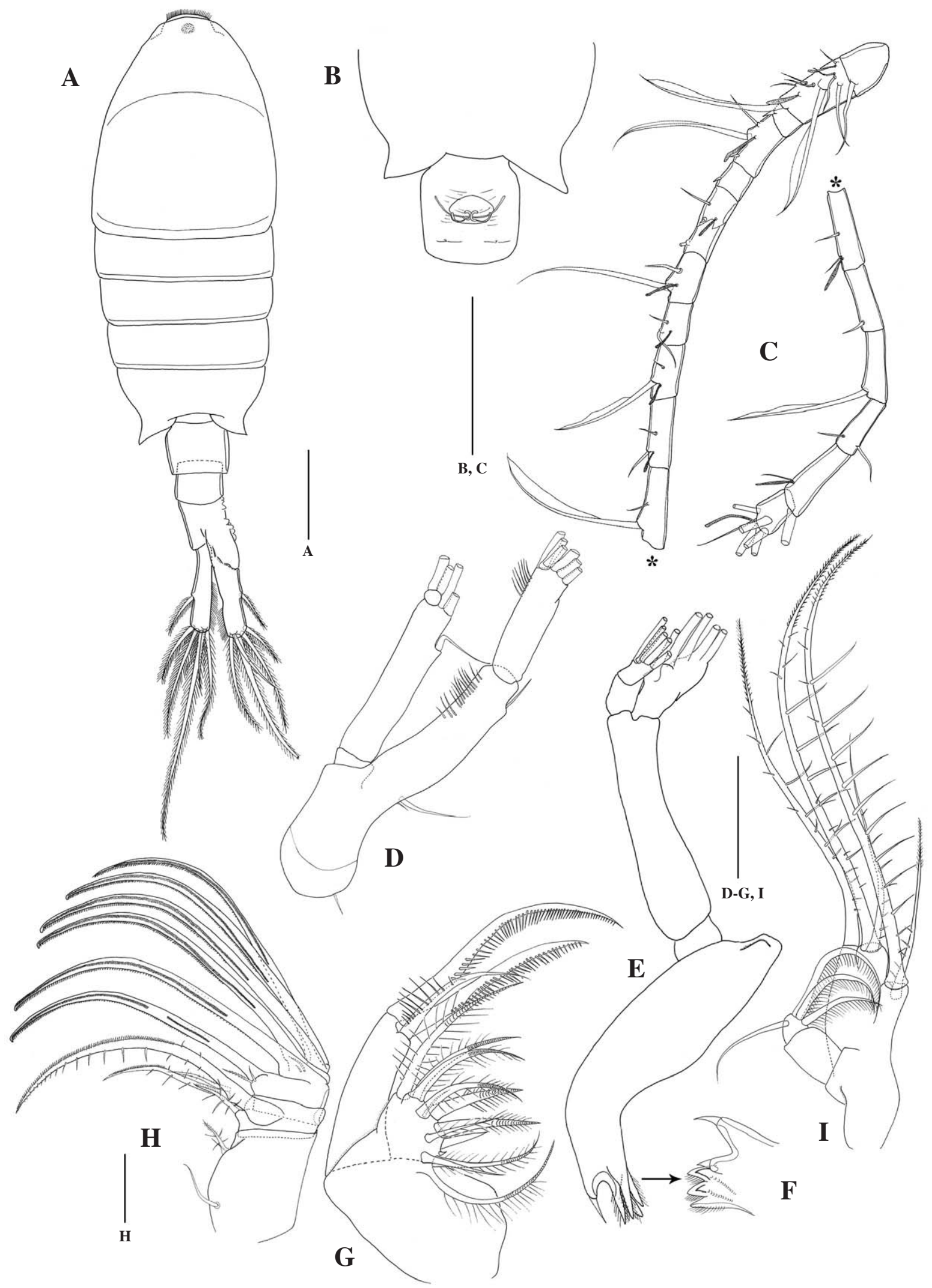

Fig. 1. Tortanus (Eutortanus) vermiculus, female. A. habitus, dorsal view. B. prosomal end and genital segment, ventral view. C. antennule. D. antenna. E. mandible. F. gnathobase of mandible. G. maxillule. H. maxilla. I. maxilliped. Scale bars: A-C $=0.25 \mathrm{~mm}$, E-I=0.1 mm. 


\section{Systematic Accounts}

Family Tortanidae Sars, 1902

Genus Tortanus Giesbrecht, 1898 (in Giesbrecht and Schmeil, 1898)

Subgenus Eutortanus Smirnov, 1935

${ }^{1 *}$ Tortanus (Eutortanus) vermiculus Shen, 1955 (Figs. 1-3)

Tortanus vermiculus Shen, 1955, 80, figs. 5-6; Chen and Zhang, 1965, 117, figs. 5-8.

Material examined. Korea: Incheon: $2 \sigma^{\top} \oslash^{7}, 5$ 우 우, Ganghwa-gun, Ganghwado Island, 1 Sep 2009, J.H. Jung; $4 \sigma^{7} \sigma^{7}, 5$ 우 우, same locality, 25 Oct 2010, B.J. Lim.

Description. Female: Body length $1.76 \mathrm{~mm}$ (Fig. 1A). Cephalosome and first pedigerous somite completely separated; fourth and fifth pedigerous somites almost completely fused. Posterior corners of last pedigerous somite slightly asymmetrical, produced posterolaterally into a triangular process. Urosome 3-segmented, distal urosomite incompletely fused with caudal rami (Fig. 1A); genital double-somite as wide as long; genital operculum located ventromedially, oval with posterior margin slightly convex (Fig. 1B); anal somite incompletely fused with left caudal ramus and almost completely with right caudal ramus having uneven dorsolateral process on anterior right side. Caudal rami asymmetrical, right ramus slightly longer than left.

Antennule (Fig. 1C) 18-segmented, ancestral segments II to IX, XI to XII, and XXVI to XXVIII completely fused. Armature as follows; I, 1; II-IX, 9+2ae; X, 1; XIXII, 3+ae; XIII, 1; XIV, 2+ae; XV, 1; XVI, 2+ae; XVII, $2+$ ae; XVIII, 2+ae; XIX, 2+ae; XX, 2; XXI, 2+ae; XXII, 1; XXIII, 1; XXIV, 1+1; XXV, 1+1+ae; XXVIXXVIII, 6+ae. Antenna (Fig. 1D) coxa with a seta; basis and endopod fused; basis with 2 unequal setae; endopod 2 -segmented, proximal segment with 1 outer seta and a row of spinules subterminally on inner margin, distal segment with 6 setae and a row of spinules subterminally. Mandible (Fig. 1E, F) with gnathobase bearing 3 mono-
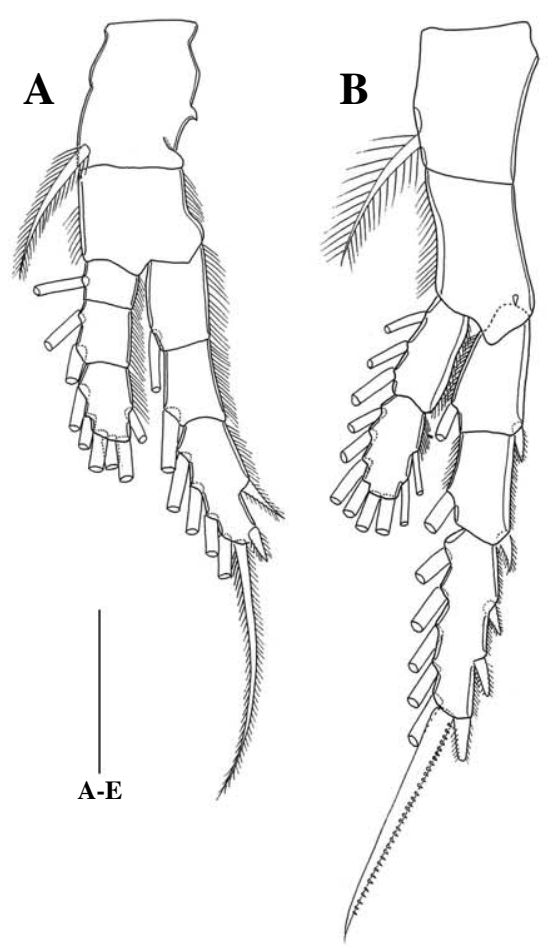
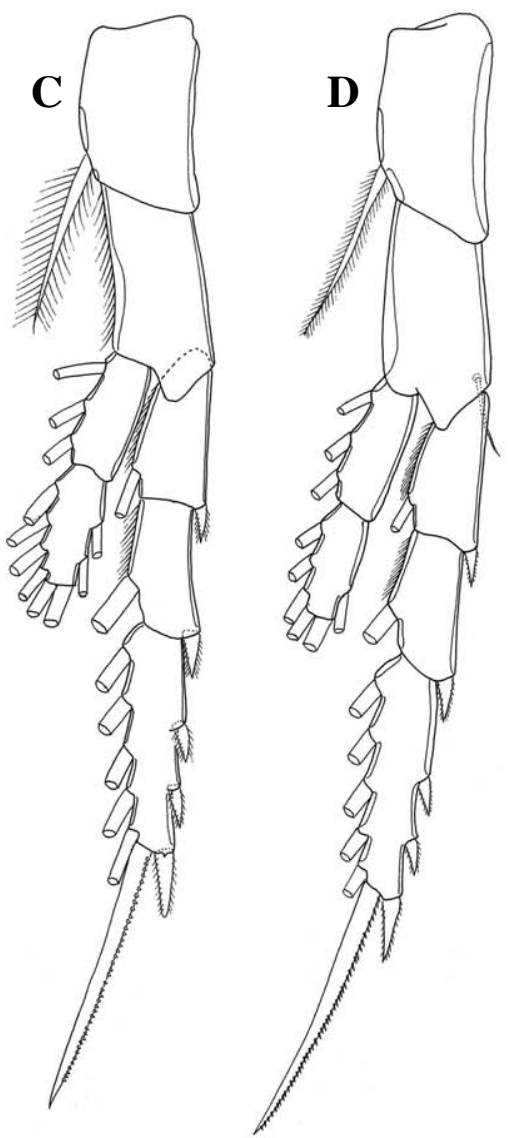

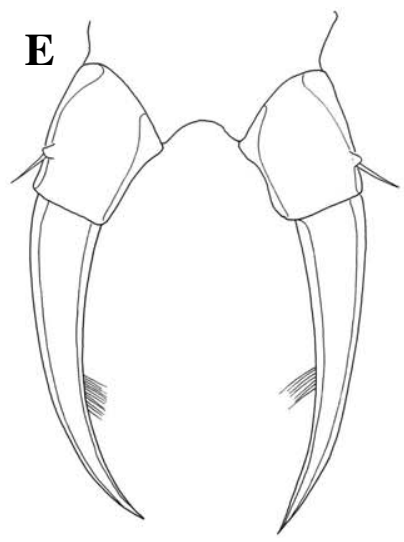

Fig. 2. Tortanus (Eutortanus) vermiculus, female. A. leg 1, anterior view. B. leg 2, anterior view. C. leg 3, anterior view. D. leg 4, anterior view. E. leg 5, anterior view. Scale bar: A-E $=0.1 \mathrm{~mm}$.

Korean name: ${ }^{1 *}$ 비대칭부푼긴노벌레 (신칭) 

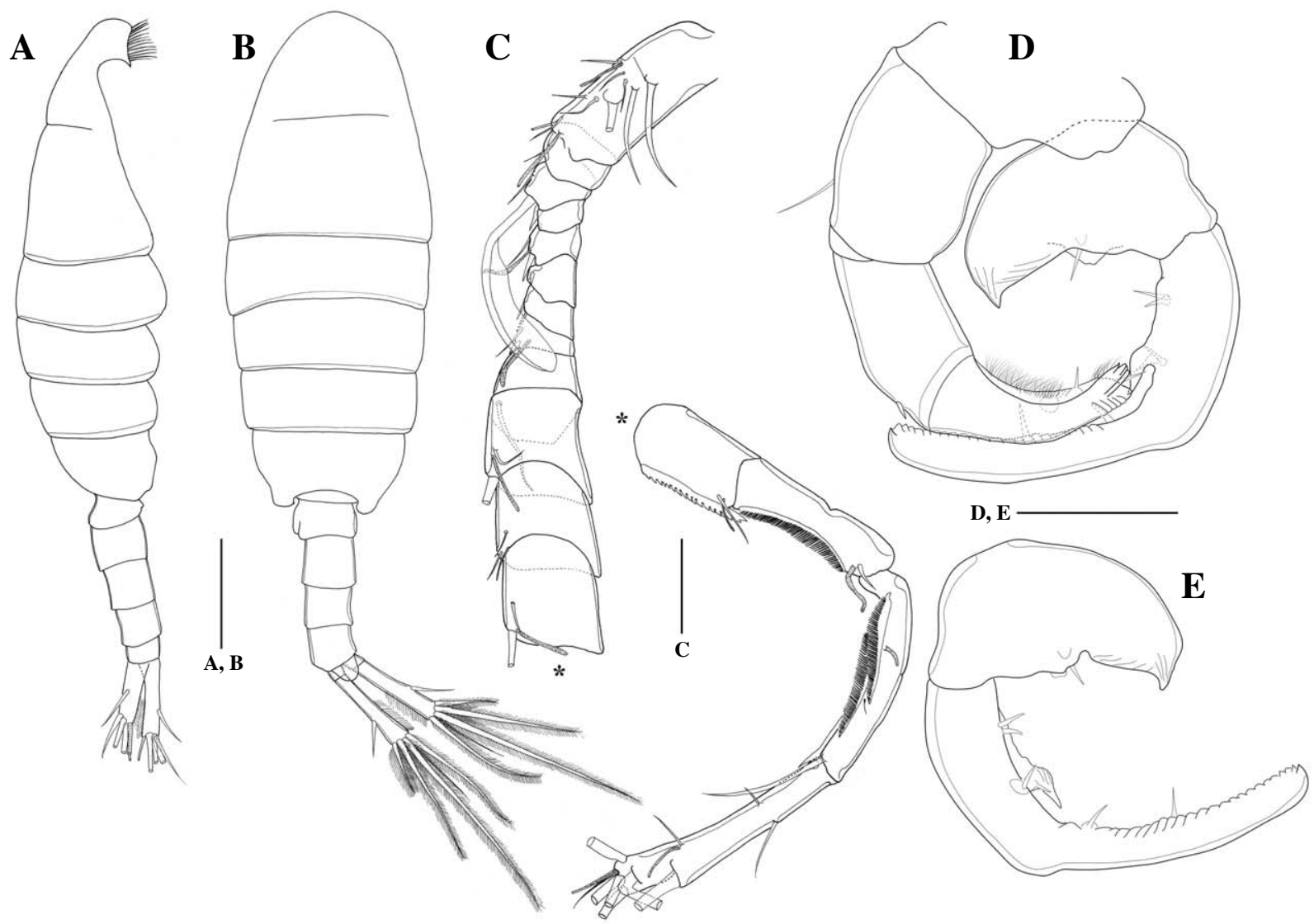

Fig. 3. Tortanus (Eutortanus) vermiculus, male. A. habitus, lateral view. B. habitus, dorsal view. C. right antennule. D. leg 5, posterior view. E. right leg 5, anterior view. Scale bars: $A, B=0.25 \mathrm{~mm}, C-E=0.1 \mathrm{~mm}$.

cuspid and 2 bicuspid teeth; endopod and exopod with 5 setae, respectively. Maxillule (Fig. 1G) without basis, endopod and exopod; praecoxal arthrite bearing 12 setae and 1 minute seta; coxal endite with 3 stout, spinulose setae. Maxilla (Fig. 1H) well developed; first and second praecoxal endites with 1 and 2 setae, respectively; first and second coxal endites with 1 and 3 setae, respectively; basal endite with 1 long and 2 short setae; endopod with 5 long and 2 rudimentary setae. Maxilliped (Fig. 1I) with setal formula of praecoxal and coxal endites: $0,2,2,1$. Basis unarmed; endopod 1-segmented, with 4 setae.

Seta and spine formula of legs 1 to 4 (Fig. 2A-D) as follows:

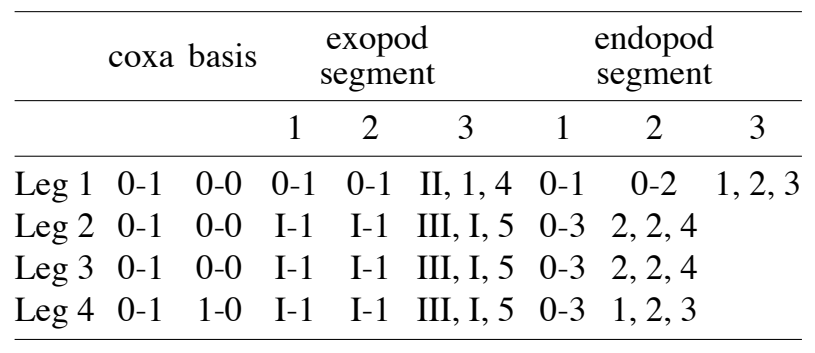

Leg 5 (Fig. 2E) 3-segmented; both coxal segments fused completely with intercoxal sclerite to form a common base; basis with a seta at point two-thirds along outer margin; exopod 1-segmented, tapering distally; both exopods with row of hairs along inner margin; left exopod slightly longer than right.

Male: Body length $1.68 \mathrm{~mm}$ (Fig. 3A, B). Cephalosome and first pedigerous somite separated; fourth and fifth pedigerous somites completely fused. Last pedigerous somite slightly asymmetrical, produced into blunt process. Urosome 5-segmented, first urosomite asymmetrical; second urosomite longest. Caudal rami asymmetrical, right ramus slightly longer than left.

Right antennule (Fig. 3C) 16-segmented and geniculate; ancestral segments I to VIII, XXI to XXIII, and XXIV to XXVIII completely or incompletely fused. Armature as follows; I-VII, 10+2ae; VIII, 1; IX, 2; X, 1; XI, 2+ae; XII, 1; XIII, 1; XIV, 2+ae; XV, 1; XVI, 2+ ae; XVII, 2+ae; XVIII, 2+ae; XIX, 1+ae+process; XX, $1+\mathrm{ae}+$ process; XXI-XXIII, $2+\mathrm{ae}+2$ processes; XXIVXXVIII, 10+2ae.

Leg 5 (Fig. 3D, E) right and left coxal segments fused to form common base. Right leg chelate; basis produced 

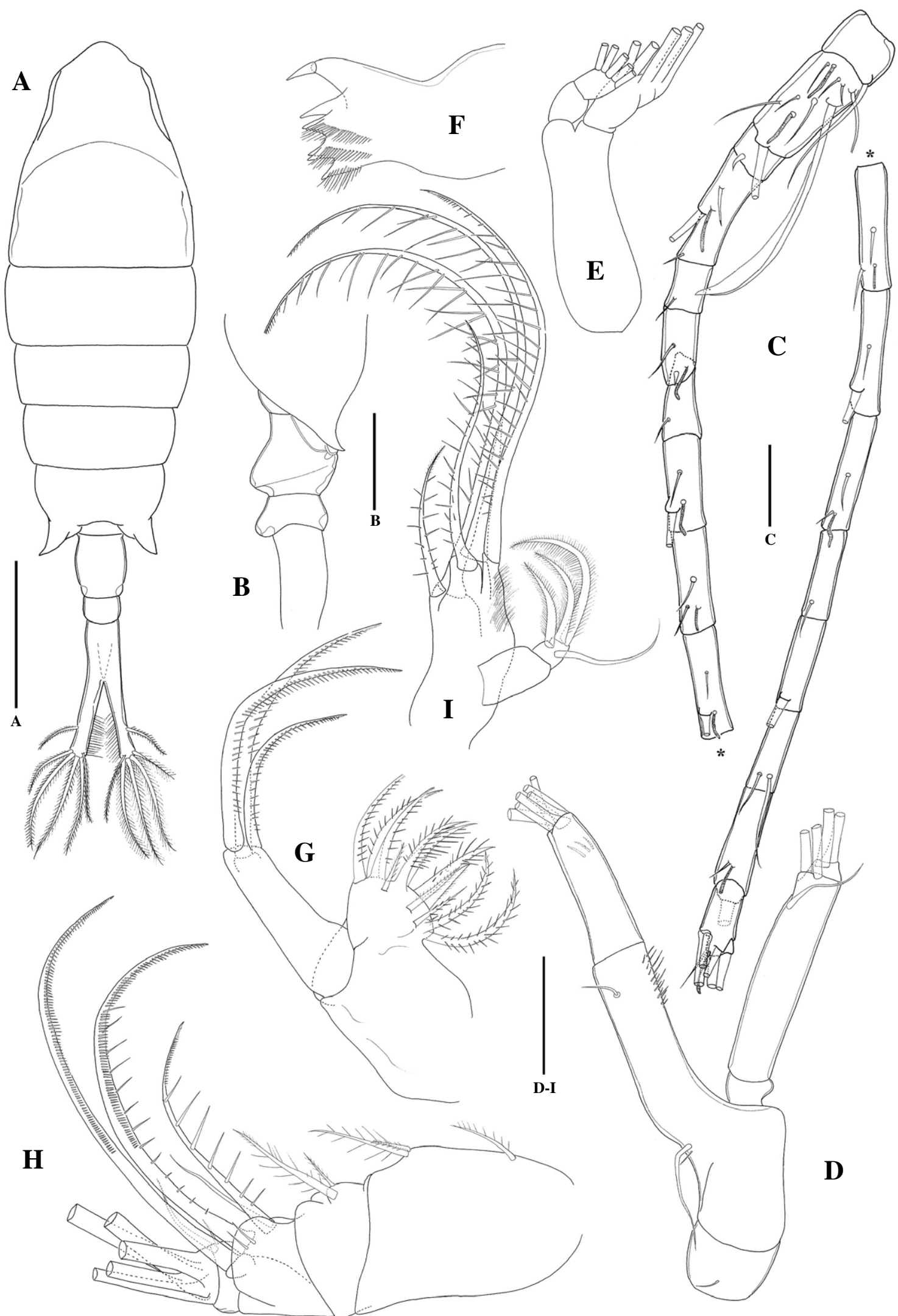

Fig. 4. Tortanus (Eutortanus) komachi, female. A. habitus, dorsal view. B. urosome, lateral view. C. antennule. D. antenna. E. palp of mandible. F. ganthobase of mandible. G. maxillule. H. maxilla. I. maxilliped. Scale bars: A $=0.5 \mathrm{~mm}, \mathrm{~B}=0.25 \mathrm{~mm}, \mathrm{C}-\mathrm{I}=0.1 \mathrm{~mm}$. 
inwards into triangular process bearing 1 seta; exopod angularly curved inwards, bearing pointed process and 6 short spines on inner margin. Basis of left leg with outer seta subterminally; exopod 2-segmented, first segment with 1 short spine subterminally, second segment with 1 distal and 2 subdistal spines.

Distribution. China (Fenghsien), Korea (Incheon).

Remarks. Shen (1955) first reported T. (E.) vermiculus from the coastal water of Fenghsien, Kiangsu Province. Later, Chen and Zhang (1965) redescribed this species from the Amoy. Until now, this species has been known as showing a restrictive distribution along the southern part of the East China Sea (Ohtsuka et al., 1992; Ohtsuka and Reid, 1998; Itoh et al., 2001). The discovery of this species in Korean waters would expand the range of the hitherto known biogeography.

It is difficult to compare original specimen, because of poor description.

Tortanus (Eutortanus) vermiculus is readily distinguished from other congeners by: anal somite and right caudal ramus of female with uneven dorsolateral process, and right exopod of leg 5 in male with long process along proximal inner margin.

The amplified DNA was $631 \mathrm{bp}$ in length. The partial CO1 sequence of $T$. (E.) vermiculus was determined for the first time and registered at GenBank (Accession no: JN605791).

${ }^{1 *}$ Tortanus (Eutortanus) komachi Itoh, Ohtsuka and Sato, 2001 (Figs. 4-6)

Tortanus (Eutortanus) komachi Itoh, Ohtsuka and Sato, 2001: 59, figs. 1-5.

Material examined. Korea: Gangwon-do: $5 \oslash^{\nearrow} \oslash^{7}$, Goseong-gun, Goseong port, 17 Apr 2011, BJ Lim; $208 \sigma^{\top} \sigma^{-1}$, 17 우 우, Gangneung-si, Gyeonso-dong, Gangneung port,

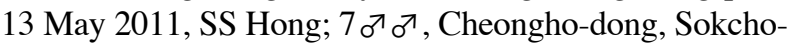
si, Cheongchoho, 12 Mar 2012, JH Song.

Description. Female: Body length $2.4 \mathrm{~mm}$ (Fig. 4A). Cephalosome and first pedigerous somite completely separated; fourth and fifth pedigerous somites incompletely fused. Posterior corners of last pedigerous somite asym-

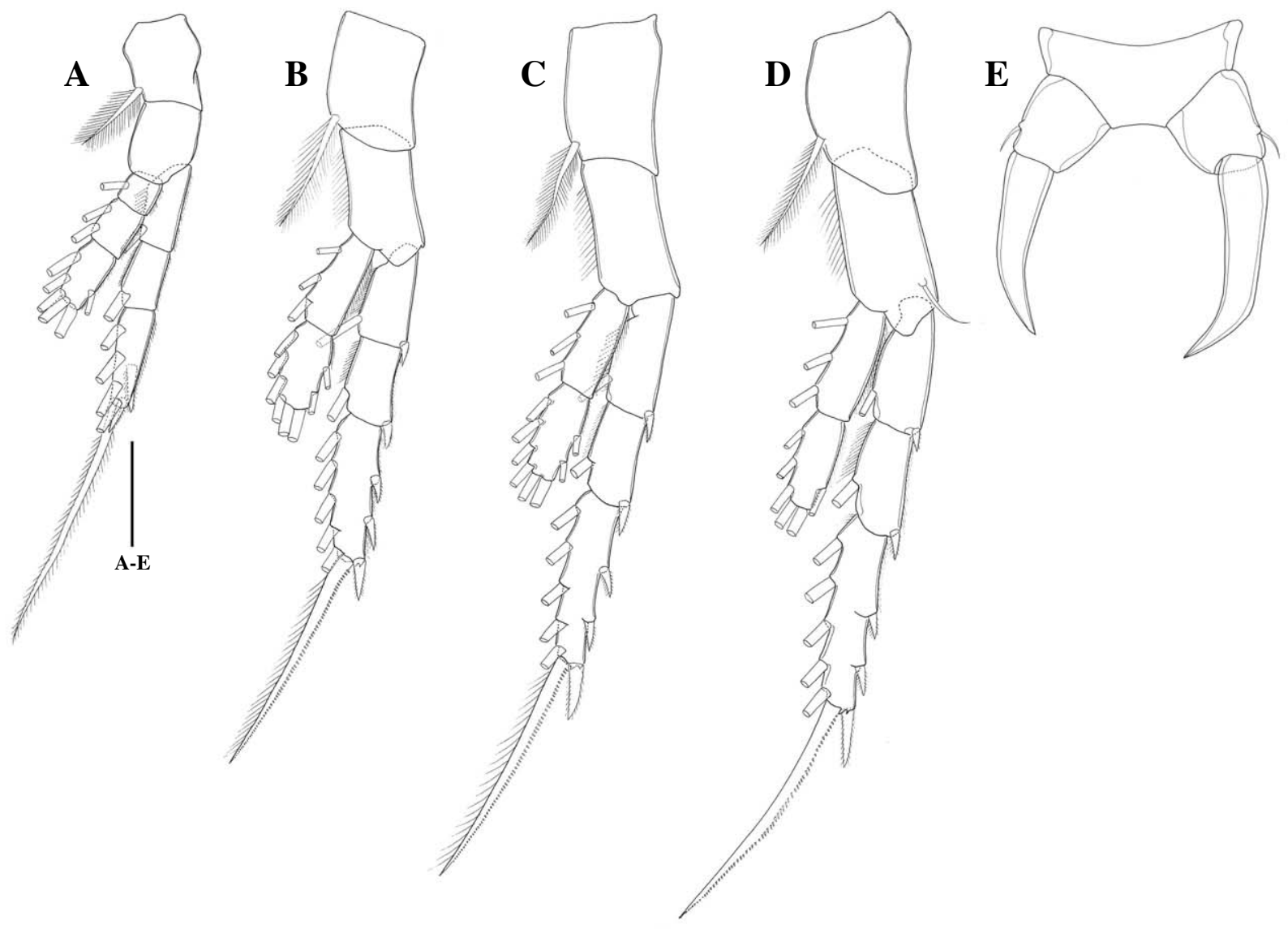

Fig. 5. Tortanus (Eutortanus) komachi, female. A. leg 1, posterior view. B. leg 2, posterior view. C. leg 3, posterior view. D. leg 4, posterior view. E. leg 5, anterior view. Scale bar: A-E=0.1 mm. 


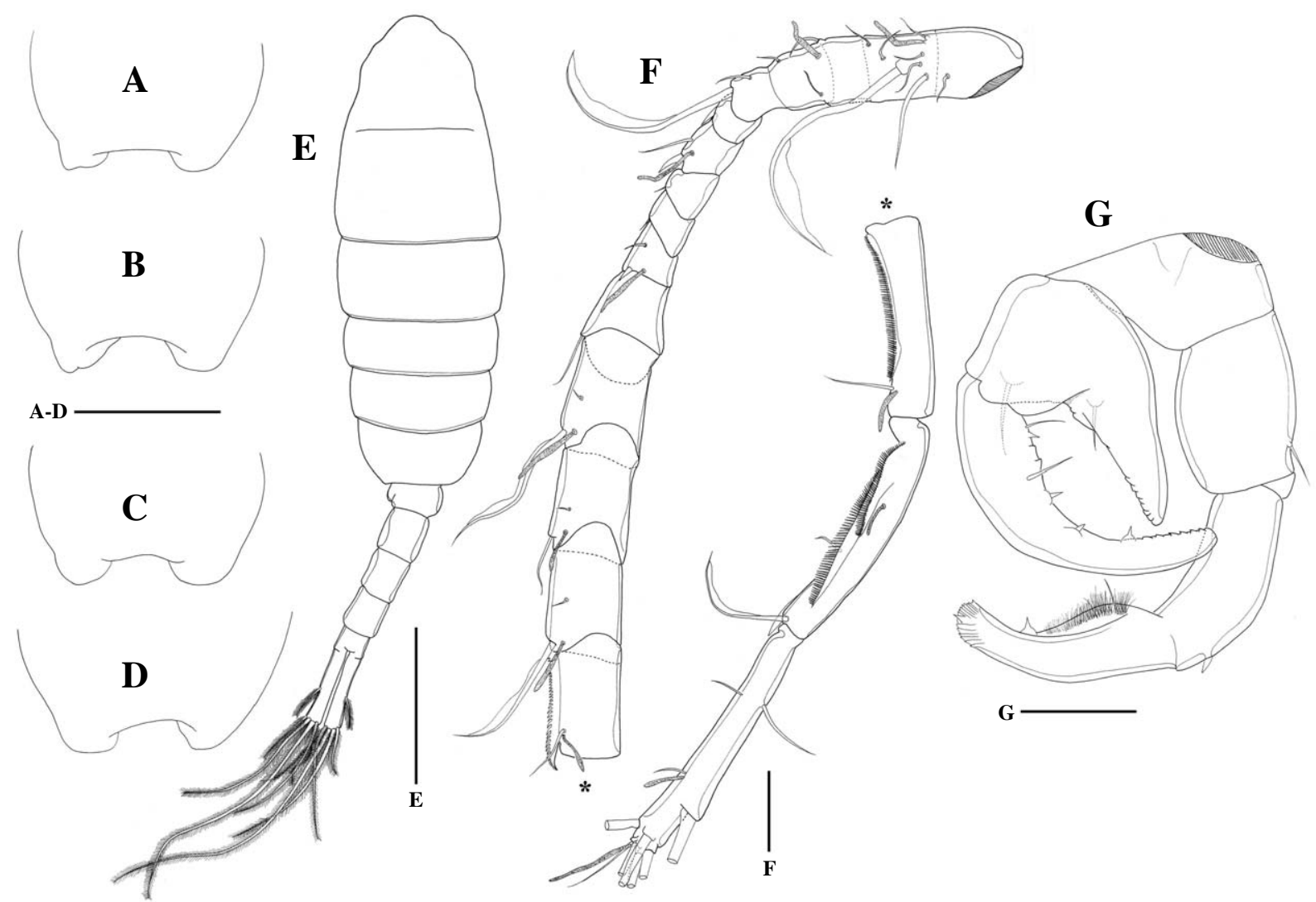

Fig. 6. Tortanus (Eutortanus) komachi, male. A-D. variability of prosomal end, dorsal view. E. habitus, dorsal view. F. right antennule. G. leg 5, anterior view. Scale bars: $A-D=0.25 \mathrm{~mm}, E=0.5 \mathrm{~mm}, \mathrm{~F}-\mathrm{G}=0.1 \mathrm{~mm}$.

metrical, produced posterolaterally into triangular process.

Urosome 3-segmented (Fig. 4A, B), genital double somite about 2 times as long as second one; third segment completely fused with caudal rami. Caudal rami asymmetrical; both ramus almost same in length.

Antennule (Fig. 4C), antenna (Fig. 4D), mandible (Fig. 4E, F), maxillule (Fig. 4G), and maxilliped (Fig. 4I) similar to those of $T$. (E.) vermiculus. Maxilla (Fig. 4H) well developed; first and second praecoxal endites with 1 and 2 setae, respectively; first and second coxal endites with 2 and 3 setae, respectively; basal endite with 1 long and 2 short setae; endopod with 5 long and 2 rudimentary setae. Armature formula of legs 1 to 4 as in $T$. (E.) vermiculus (Fig. 5A-D).

Leg 5 (Fig. 5E) 3-segmented; basis with seta on outer margin; exopod 1-segmented, left exopod slightly longer than right; endopod absent.

Male: Body length $2.3 \mathrm{~mm}$ (Fig. 6E). Prosome about 1.8 times as long as urosome. Cephalosome and first pedigerous somite completely separated; fourth and fifth pedigerous somites incompletely fused. Posterior corners of last pedigerous somite asymmetrical, produced postero- laterally into blunt process (Fig. 6A-D).

Urosome 5-segmented, second to fourth segments subequal in length; distal segment incompletely fused with caudal rami. Caudal rami asymmetrical, right ramus slightly longer than left.

Right antennule (Fig. 6F) 15-segmented and geniculate; ancestral segments I to VIII, XXI to XXIII, and XXIV to XXVIII completely or incompletely fused. Armature as follows; I-VIII, 11+2ae; IX, 2; X, 1; XI, 2+ae; XII, 1; XIII, 1; XIV, 2+ae; XV, 1; XVI, 2+ae; XVII, 2+ae; XVIII, $2+$ ae; XIX, $1+$ ae+process; XX, $1+$ ae+process; XXI-XXIII, $2+\mathrm{ae}+2$ processes; XXIV-XXVIII, $10+2 \mathrm{ae}$.

Right leg 5 (Fig. 6G) 2-segmented; basis produced inwards into a long isosceles triangular process with 2 setae on posterior surface; exopod with 2 long and 4 short spines along inner margin. Left leg 2-segmented; first segment with a seta on outer margin; second and third segments incompletely fused and with 1 medial spine on outer margin, 3 spines on inner margin and 1 terminal short spine.

Distribution. Korea (East Sea), Japan (south coast of Akita).

Remarks. The Korean specimens coincide well with the 
Japanese specimen of the original description with the following two minor differences: (1) the fifth pedigerous somite of male produced posteriorly into blunt process in the Japanese specimen, but the present specimens display a slightly sharp process; (2) right caudal ramus is slightly longer than left one in the original specimen, but the caudal rami of the present Korean specimen are almost same in length.

The amplified DNA was $614 \mathrm{bp}$ in length. The partial CO1 sequence of $T$. (E.) komachi was determined for the first time and registered at GenBank (Accession no: JN605792).

\section{Key to the species of subgenus Eutortanus from Korea}

1. Urosome 3-segmented ….................. 2 (female)

Urosome 5-segmented ….....................6 (male)

2. Female right caudal ramus unarmed on right side $\cdots 3$ Female right caudal ramus having uneven dorsolateral process on anterior right side

T. vermiculus

3. Female anal somite with spiniform process on right side ….............................. spinicaudatus Female anal somite without spiniform process …... 4

4. Third urosomal segment and caudal rami completely fused T. komachi Third urosomal segment and caudal rami completely

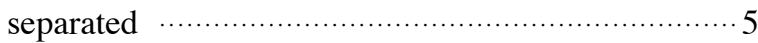

5. Anal somite with anterolateral process

T. dextrilobatus

Anal somite without anterolateral process T. derjugini

6. Right exopod of leg 5 with a pointed process on inner proximal margin ......................... vermiculus Right exopod of leg 5 without a pointed process on inner proximal margin ...7

7. Right exopod of leg 5 with not extending beyond inner proximal process on basis …....T. spinicaudatus Right exopod of leg 5 with exceeding beyond inner

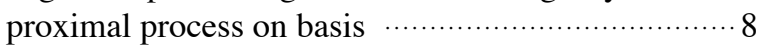

8. Basis of right leg 5 produced inwards into a long isosceles triangular process …................ T. komachi Basis of right leg 5 not produced inwards into a long

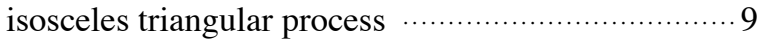

9. Basis of right leg 5 relatively narrower $\cdots T$. derjugini Basis of right leg 5 relatively wider

T. dextrilobatus

\section{ACKNOWLedGements}

This work was supported by a grant from the National Institute of Biological Resources (NIBR), funded by the Ministry of Environment (MOE) of the Republic of Korea
(NIBR NO. 2013-02-001).

\section{REFERENCES}

Chen, Q.C. and S.Z. Zhang. 1965. The planktonic copepods of the Yellow Sea and the East China Sea. 1. Calanoida. Studia Marina Sinica 7:20-131.

Folmer, O., M. Black, W. Hoeh, R. Lutz and R. Vrijenhoek. 1994. DNA primers for amplification of mitochondrial cytochrome $c$ oxidase subunit 1 from diverse metazoan invertebrates. Molecular Marine Biology and Biotechnology 3:294-299.

Hulsemann, H. 1988. Tortanus sheni, new name, replacement name for Tortanus denticulatus Shen and Lee, 1963 (Copepoda: Calanoida). Journal of Crustacean Biology 8(4): 656.

Itoh, H., S. Ohtsuka and T. Sato. 2001. New species of Tortanus (Copepoda: Calanoida) from stomach contents of chum salmon juveniles collected from the Sea of Japan. Plankton Biology and Ecology 48(1):59-67.

Kim, D.Y. 1985. Taxonomical study on calanoid (Crustacea: Copepoda) in Korean Waters. PhD dissertation, Hanyang University, Seoul, Korea, pp. 1-180.

Ohtsuka, S. and J.W. Reid. 1998. Phylogeny and zoogeography of the planktonic copepod genus Tortanus (Calanoida: Tortanidae), with establishment of a new subgenus and descriptions of two new species. Journal of Crustacean Biology 18:774-807.

Ohtsuka, S., H. Ueda and G.S. Lian. 1995. Tortanus derjugini Smirnov (Copepoda: Calanoida) from the Ariake Sea, western Japan, with notes on the zoogeography of brackish-water calanoid copepods in east Asia. Bulletin of Plankton Society of Japan 42(2):147-162.

Ohtsuka, S., Y.H. Yoon and Y. Endo. 1992. Taxonomic studies on brackish copepods in Korean waters. I Redescription of Tortanus dextrilobatus Chen and Zhang, 1965 from Korean waters, with remarks on zoogeography of the subgenus Eutortanus. Journal of the Oceanological Society of Korea 27(2):112-122.

Shen, C.J. 1955. On some marine crustaceans from the coastal water of Fenghsien, Kiangsu Province. Acta Zoologica Sinica 7:75-100.

Shen, C.J. and S.O. Bai. 1956. The marine copepod from the spawning. Acta Zoologica Sinica 8(2):177-234.

Smirnov, S.S. 1935. K faune Copepoda Amurskogo limana. Zur Copepoden-fauna des Amur-Limans. Issledovaniya Morei USSR 22:41-53.

Soh, H.Y. 2010. Invertebrate Fauna of Korea, vol. 21, no. 3: Marine Planktonic Copepods. National Institute of Biological Resources Ministry of Environment.

Submitted: September 17, 2013, Accepted: December 31, 2013 